\title{
Investigation on the Absorption of Kerosene for the Acetone vapor
}

\author{
正 中原崇文（愛知工大） 吉川倰夫（愛知工大） \\ 学 O岡田教嗣（愛知工大）大西知志（愛知工大） \\ 安江 洋 (愛知工大)
}

Takafumi NAKAHARA, Toshio YOSHIKAWA, Noritsugu OKADA, Tomoshi OHNISHI, Hiroshi YASUE

Dept. of Mech. Eng., Aichi Institute of Technology ., Yakusacho, Toyota, Aichi

\begin{abstract}
The advanced treatment for the chips, industrial waste discharged from high speed grinding process (about 80ton/month), was investigated To confirm the separation technology of machine oil from chips, absorbing ahereateristics of kerosene for acetone vapor, absorption rate in bubbling layer and residence time in spray tower were measured Henry's constant and Sh-Re relations were calculated Residence time in spray tower of $200 \mathrm{~mm}$ diameter and $2 \mathrm{~m}$ height with three spraying nozzle was investigated
\end{abstract}

\section{1 腥言}

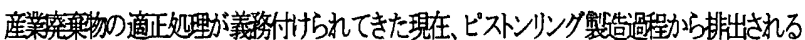

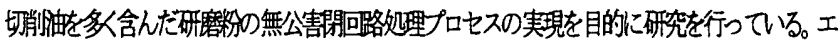

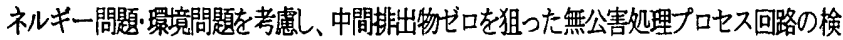
討老行、図1に示拉う方式考案した。

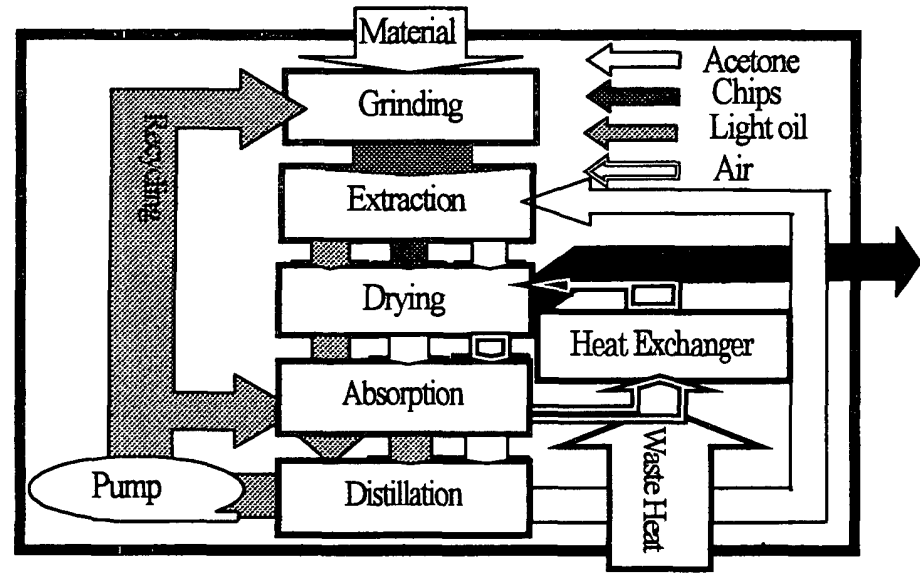

Fig.1 Treatment process flow

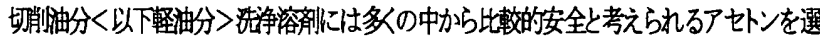

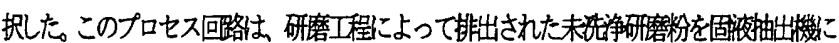

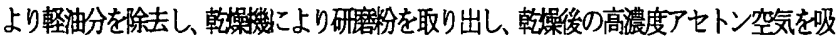

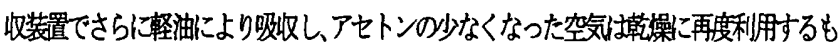

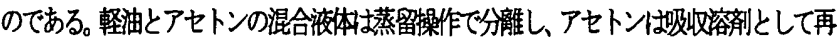

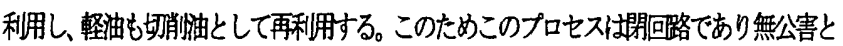

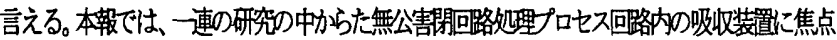

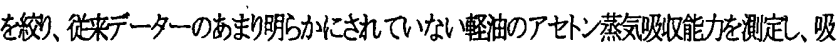

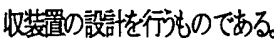

\section{2. 整油によるアセ卜吸枚器置}

フロセス回路全体の省エネルキー化を考虑して、スルー方式を採用した。

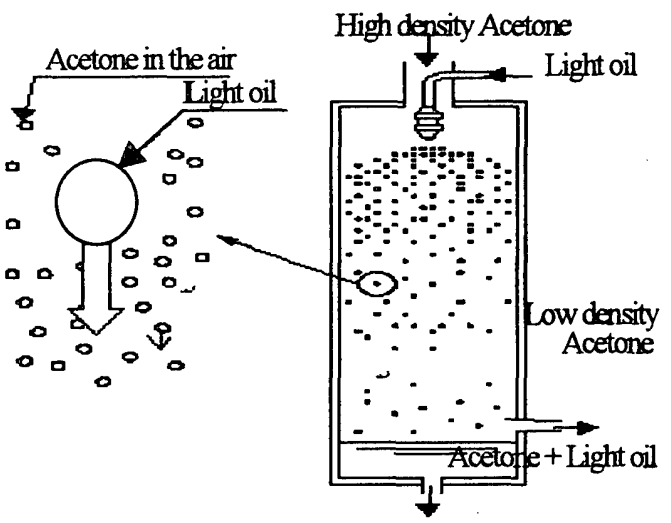

Fig.2 Spraying Absorption

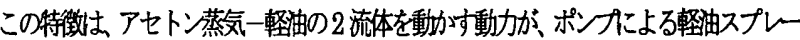
噴霧のみで、微粒化された高速軽油滴がセト蒸気と誘引俌度差によってアセトンを吸 収しようとするもので、図2にその構想を示す。装設計の基本データーは、この構造の 機能を分解し、(1軽油のアセ卜ン限界吸叫能力の把握，(2)流動状態の軽由のアセ卜ン吸収率測

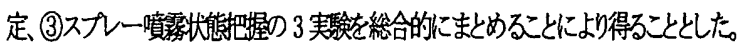
(1) 整妯のアセ卜ン限界吸收能力

吸收媒体である軽油が気体中のアセトン蒸気火十分に接触し、平衡状態に達した時が軽 油のアセトン吸收限界能力といえる。カスクロマトグラフにより測定したカス中のアセト蒸 気瓜 $\mathrm{P}\left(\mathrm{N} / \mathrm{m}^{2}\right)$ と軽油中のアセトンモル濃度 $\mathrm{C}\left(\mathrm{mol} / \mathrm{m}^{3}\right)$ の平衡状態における比は激度の低い 頒域では比例関係にあり、この比例定数であるヘンリー定数 $\mathrm{H}(\mathrm{N} \cdot \mathrm{m} / \mathrm{mol})$ を求める。

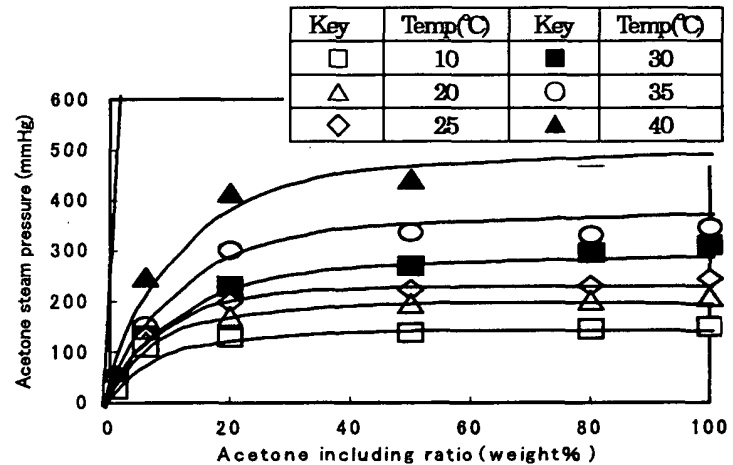

Fig.3 Test results of Abscribing performance

日本機械学会東海支部第49期総会講演会講演論文集（'00．3．10-11）No.003-1 


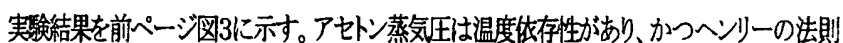

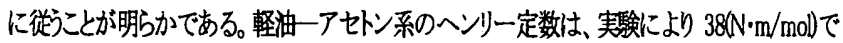
あることがわからた。

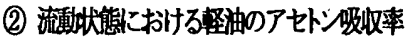

流動状態およひ制限された接触時間内における吸收の変化を湘定し、吸收速度を求める。 一般化するため流れの状態をレイノルズ数(Re)、アセトンの物質移動(吸収)の状態をシャー ウッ数(Sh)用い以下のように定義する。

$$
\operatorname{Re}=\frac{V d}{v} \quad S h=\frac{k_{L} d}{D}
$$

$\mathrm{V}:$ 気泡上昇速度 $(\mathrm{m} / \mathrm{s}) \quad \mathrm{k}_{\mathrm{L}}$ :アセトンに対する軽油の液境莫物質移動俰数 $(\mathrm{m} / \mathrm{s})$ $\mathrm{d}:$ 気泡直径 $(\mathrm{m}) \quad \mathrm{d}$ :気泡直径 $(\mathrm{m})$

$v$ : 軽油の動粘度 $\left(\mathrm{m}^{2} / \mathrm{s}\right) \quad$ D:軽油内のアセ卜ン拡散姀数 $\left(\mathrm{m}^{2} / \mathrm{s}\right)$

軽油の入っている簡易吸収塔に気泡状のアセ卜ン空気を一定の流量で送り込み、吸收塔 内部で気泡上昇中にアセ卜ン吸收を行なわせる。シャーウッ快数算出に必要とされる液境

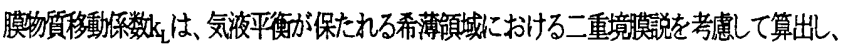

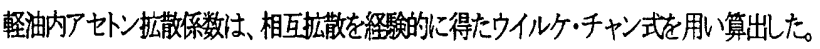
その際に必要な気泡の観察に当たっては、ハスピードカメラにより気泡直径、単位時間に おける発生気泡の個数、気泡上昇速度を測定した。以下に軽油の飽和アセ卜蒸気吸収力 の結果と不飽和アセ卜蒸気に対する吸収力の結果を示寸

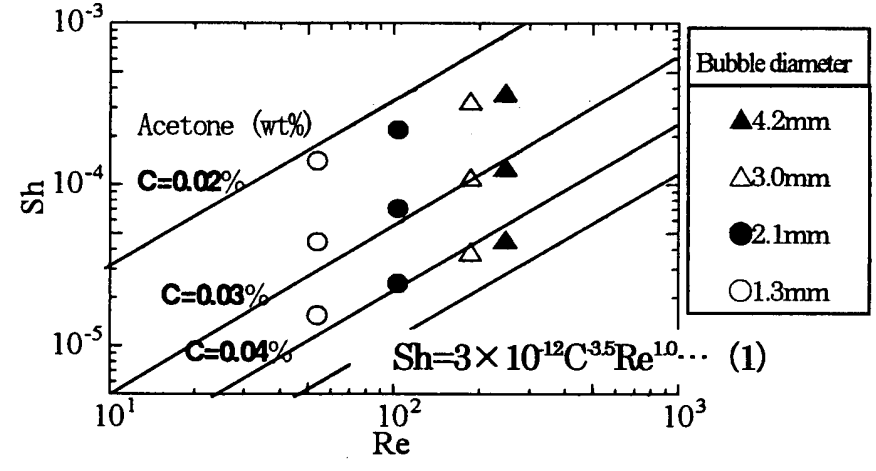

Fig.4 Absorption rate under saturated condition

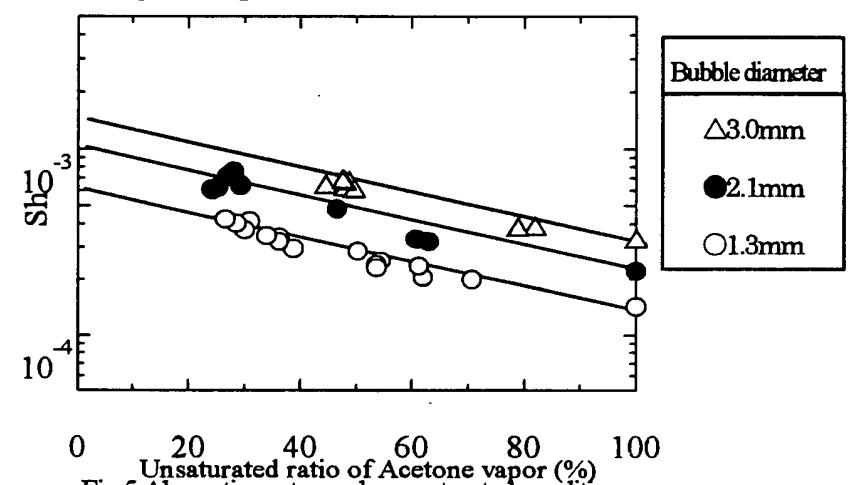

Fig.5 Absorption rate under unsaturated condition

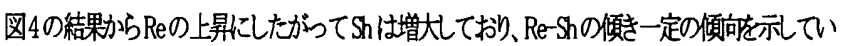

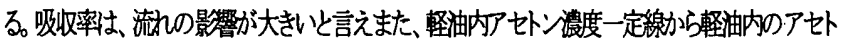

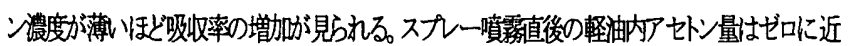

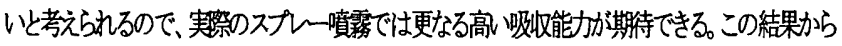

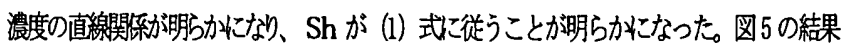

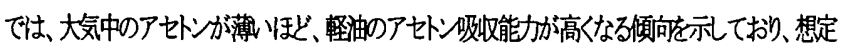
される帮祭の吸収に有利よ結果を示している。

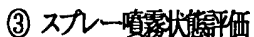

スプー並流收收方式ではスプー塔の高さはあまり高してもスプレー後の時間が経 過すると相対速度が小さくなるため、能力は餙和に達してしまう。実用规模の1ユニッ忆して 直径 $200 \mathrm{~mm}$ 、長さ $2 \mathrm{~m}$ のスプー式财収塔を考えた。のユニットでの処理能力を明確にす るととにより、実プラントはユニッ数を必要数増設するととで対応できる。アセトンと軽油を 実験に用いるのは非常に危険であるので、水一空気柇たけけるスプレ一液滴流動状態を把 握することとした。

スプレー吸收では水滴の有効接触面積と、空気流入速度を考虑した水滴落下速度との 相対速度が影䇾するので、相対レイノルス数Re $\mathrm{r}_{\mathrm{r}}$ を定義する。

$$
\operatorname{Re}_{\mathbf{r}}=\frac{d(\mathrm{Ve}-\mathrm{Va})}{\nu}
$$

$\mathrm{d}$ :代表長さ(水滴直径) (m) Ve:水滴落下速度 $(\mathrm{m} / \mathrm{s})$

$\mathrm{Va}$ :空気流入速度 $(\mathrm{m} / \mathrm{s}) \quad v$ : 空気の動粘性保数 $\left(\mathrm{m}^{2} / \mathrm{s}\right)$

スプーハスル出口径を出口径0.7,20,3.5mmの3種類を用意し、Rer上有效接触面積の 関俰を謂べ検討する。水谪落下速度は、円筒出口を落下寸る水滴をハイスピードカメラによ り測定した。

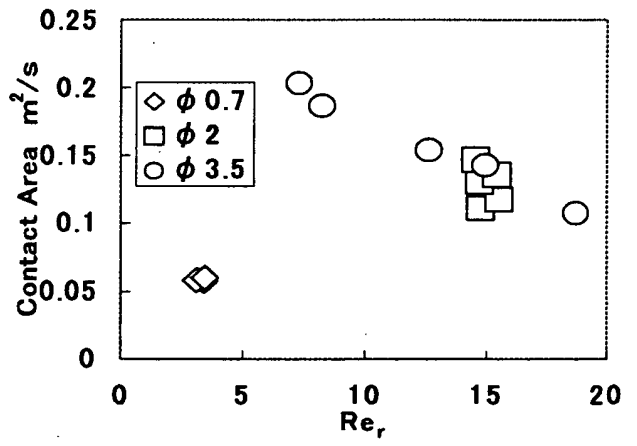

Fig.6 Compreasion of spraying performance

出口径の小さなバル $\phi 0.7 、 \phi 2.0$ の結果は、吸収塔出口のRe $\mathrm{T}$ の収束が見られる。れは 吸收塔の高、吸収能力持つ䇳用が非常に短いことを示しており、吸收塔の高さを低てさる 利点がある。大粒径賁霧/ズルの結果は吸收能力がスプレー噴霧出口任に大きく传存寸る 結果を示しており大きな流れを起し吸收を行う利点があるといえる。またス九ー噴霧に 必要な動力に対して、実祭に同伴流入した空気々落下た水湖の動力の割合を算出した。

Table.1 Test results of Spraying power performance

\begin{tabular}{|c|c|}
\hline Nozzle size $(\mathrm{mm})$ & 0.72 .03 .5 \\
\hline Spraying efficiency $(\%)$ & $20 \sim 30$ \\
\hline
\end{tabular}

実察に入力する動力に対して20〜30\%の効率て吸收操假行えることがわからた。 3 結言

(1)(2)(結果を統合して、スプー吸收装置の能力を試算すると以下のことがかからた。

（1）軽油のアセトン限界吸収量を、低濃度希薄領域における吸收状態を示寸へンリー定

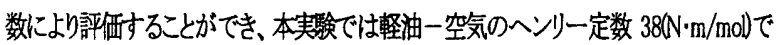
あることがわからた。

（2）スフルー吸收装置を提案し、流動圤態の吸收仮定をSh-Re で評伍するととがでた。 吸收率(Sh)は軽油ないアセ卜ンの量が薄い程大きく、流動(Re)が活発なほど吸収率 が高、傾向走示しており、この関保を $S h=3 \times 10^{-12} \mathrm{C}^{-3.5} \mathrm{Re}^{1.0}$ と示すことができた。 また、不䬶和なアやト蒸気はど吸收率が高いということがかがた。

\section{参考文献}

1. T. Nakahara, T. Yoshikawa, and N. Okada, "Investigation of the Utilization of the Chips Tasted from the HighSpeed Grinding Process", 2nd International Symposium on Advanced Energy Conversion system and Related Technologies RAN8, 1998-12, pp. 130-131 